\title{
ROBERT EARLE BUCHANAN
}

\author{
1883-1973
}

Buchanan is dead! This news was conveyed to me by Roger Porter in a letter dated 23 February 1973. In the same mail, I received a manuscript to review for the International Journal of Systematic Bacteriology in which a statement commenced, "According to Buchanan...."Buchanan was very much alive-and so he will remain for a long period to come in any matters connected with his one consuming interest in life-bacterial taxonomy and nomenclature.

The history of achievements of Dr. Robert Earle Buchanan has been ably recorded by Brooks (1972), so my comments will be restricted mainly to those related to his association with Bergey's Manual and with the International Committee on Systematic Bacteriology.

Dr. Buchanan was born of Scottish parents in 1883. He was reared on a farm and had his first introduction to education in biology at the age of 9. According to Brooks, he took high school courses in botany and biology and later a college course in Latin "taught by the football coach." The significance of the latter record is not immediately evident, but he certainly kicked the Latin (and Greek) around with much fervor in later life.

He later studied under Louis $\mathrm{H}$. Pammel in Iowa State College, now Iowa State University, where he took his Master's degree in Bacteriology in 1906. He took his doctorate in Chicago in 1908, returned to Iowa, married Estelle Fogel, and with her published a textbook in bacteriology in 1913. He organized the first Department of Bacteriology at Iowa State College in 1910 , retaining the headship of that Department until his retirement in 1948. He was Dean of the Graduate C.ollege from 1919 to 1948.

In 1918 he was elected President of the American Society of American Bacteriologists.

In 1926 he became the first editor of the Iowa State Journal of Science, retiring from that office in 1972 .

His first excursion into the field of literature relating to bacterial taxonomy was in 1917 with the publication in the Journal of Bacteriology of a paper titled "Studies on the nomenclature and classification of bacteria: the problems of bacterial nomenclature" in which he pro- posed the development of a code of nomenclature for bacteria based on the codes of nomenclature of botany and zoology, and he supported the use of Latin and Greek stems for nomenclature.

He was a member of a committee consisting of Winslow, Broadhurst, Buchanan, Krumweide, and Smith which, in September 1917 , submitted the "Preliminary Report of the Committee of the Society of American Bacteriologists on Characterization and Classification of Bacterial Types."

As Vice-President and later President (1918) of the Society of American Bacteriologists, he was (to use his own words) "... somewhat involved in the proposal that a Manual of Determinative Bacteriology be sponsored by the Society ....," and he later sent "thirty typed pages of suggestions to Dr. Bergey" for correction of errors detected in the first edition of Bergey's Manual.

Having, at a later date, been the recipient of a 22-page commentary on the first draft of the keys for the seventh edition of Bergey's Manual, I can well appreciate the feelings of Dr. Bergey who "... did not acknowledge the letter ... (but) corrected the errors." These two instances, of which there were many, emphasize the thoroughness with which Dr. Buchanan addressed himself to matters in taxonomy and nomenclature and for which many remain continually indebted to him.

Surprising as it will no doubt seem to many, Dr. Buchanan was never directly associated with the editorship of Bergey's Manual until the death of Dr. Robert S. Breed, at the time that the seventh edition went to press. He was, however, associated with the several editions of the Manual as a contributor.

He prepared a new introduction to the fourth edition of the Manual and prepared the revision of the Order Myxobacterales for that edition, amendments to which continued to appear through the seventh edition.

Commencing with the sixth edition of the Manual, Dr. Buchanan "was asked to visé the etymology of the names of taxa," a task which he was continuing for the eighth edition of the Manual at the time of his death. Many people will remember him for his freely given advice in this area. 
In the seventh edition, he added the tasks of updating the information on the genus Paraspirillum, the Order Beggiatoales, and the families Beggiatoaceae and Leucotrichaceae from the literature.

He did not become a member of the Board of Trustees of Bergey's Manual until after the final organization of the material for the seventh edition, having declined earlier preretirement invitations because of the heavy administrative load of his office at Iowa State College.

Most will recall that Dr. Breed radically altered the form of the seventh edition of the Manual over that adopted for the sixth, and the task of editing what Dr. Breed had intended as a second volume of the seventh edition-and which ultimately appeared as Index Bergey$a n a-f e l l$ to Drs. Buchanan, Holt, and Lessel.

After the death of Breed, Buchanan was elected Chairman of the Board of Trustees of Bergey's Manual. He occupied this post until his death. Declining health necessitated that he relinquish the editorship of the eighth edition of the Manual to Dr. N. E. Gibbons, but he still retained his right to "visé the etymology of the names of the taxa."

Although Dr. Buchanan's connections with Bergey's Manual may, during the earlier period, have been of a secondary nature, his activities at the international level were not. The Winslow Committee in 1917 had recommended to the Society of American Bacteriologists that the international rules of botanical nomenclature be accepted by the Society as governing bacterial terminology, with the exception that French, English, and German be substituted for Latin in the diagnoses and that the date of publication of the third edition of Zopf's Spaltpilze (1883) be considered as the date for the beginning of nomenclature for the purpose of determining priorities-with certain exceptions.

Subsequently, the Committee on Nomenclature of the Botanical Society of America proposed a type-basis code of botanical nomenclature which later influenced decisions for the bacteria.

In 1913, Vuillemin heralded the separation of bacteriological nomenclature from botanical nomenclature, suggesting 1915 as a departure date. Buchanan, in his 1917 publication, proposed the development of a system of bacterial nomenclature based on the botanical and zoological codes.

In 1930, the first International Congress for Microbiology was convened in Paris under the auspices of the Pasteur Institute. (This is the official statement. A verbal commentary by the late Professor Everitt Murray suggests that Dr. Buchanan could have added much color to literature in microbiology with an unofficial history of the location and proceedings of that Congress!) Dr. Buchanan was invited as a representative of the Society of American Bacteriologists. He "... corresponded with the members of the organizing committee of the Congress stressing the need of a Committee (corresponding somewhat to similar committees in botany and zoology) that could undertake formulation of international relationships to problems of bacterial nomenclature.... One of the early items of business was the passage of a motion that an ad hoc committee be set up to consider problems of bacteriological nomenclature and the possible organization of a continuing international agency." Dr. Buchanan was a member of this ad hoc committee and of a subcommittee assigned the task of drafting a resolution which subsequently resulted in the establishment "as a permanent agency of the International Association of Microbiological Societies a provision for the organization of an International Committee on Nomenclature of Bacteria," with Dr. Ledingham (Lister Institute, London) as Chairman and two continuing Secretaries, one for medical and one for non-medical microbiology (Dr. St. John Brooks and Dr. Breed, respectively,-the latter recommended by Dr. Buchanan).

Dr. Buchanan chaired the Section on Microbiology of the Paris Congress, and was commissioned by that Congress "... to present to the Nomenclatural Section of the Botanical Congress held later in 1930 the request that the bacteria should not be included in the Botanical Code requirement that description of new species in order to be validly published, must be printed in Latin." The recommendation was considered and approved.

At the Second International Congress for Microbiology, held in London in 1936, a decision was taken to establish an independent code of nomenclature for bacteria.

Tentative international rules of bacteriological nomenclature were prepared by a U.S.A.Canadian Committee and presented to the third Congress, held in New York in 1939. At that Congress, the ICNB authorized the establishment of a Judicial Commission on Nomenclature, and Dr. Buchanan was elected as Chairman pro tem. He occupied this post until 1966.

The new Judicial Commission was directed to prepare a code for the next Congress. Dr. Buchanan chaired "the succession of commit- 
tees that worked on the preparation of the Code which was finally approved at the much-delayed (by war) fourth Congress held in Copenhagen in 1947." The Code was published in 1948 and has been amended at subsequent Congresses.

At the 1950 Congress in Rio de Janeiro, the then ICNB authorized the publication of the International Bulletin of Bacteriological Nomenclature and Taxonomy-later to become the International Journal of Systematic Bacteriology. Dr. Buchanan was appointed editor of the Bulletin and remained editor until his resignation from that post in 1970 , when he was replaced by his one-time assistant at Iowa State University, Erwin F. Lessel.

The Bulletin was established as "... the best method of maintaining the necessary contacts between and among the members of the Judicial Commission, of the International Committee, and of the several subcommittees on nomenclature and taxonomy, of special groups of microorganisms of economic and medical significance." It was to publish: (i) the official actions of the Judicial Commission of the International Congresses, including amendments to the International Code of Nomenclature of Bacteria and Viruses and the official Opinions of the Judicial Commission; (ii) reviews of each case in which suspension of a rule is asked, and the resultant decisions; (iii) the lists of names of taxa that should be conserved, including lists of conserved generic names and lists of the names against which these names are conserved; (iv) subcommittee reports and minutes and their recommendations on nomenclature and taxonomy; (v) lists of type species of bacterial genera and of the type genera of higher taxa and the designations of type strains.

As such, the Bulletin lacked appeal "to the masses" and consequently suffered from a low circulation and the monetary restrictions associated with such publications. Perhaps it pays credit to Dr. Buchanan's Scottish ancestry that he managed to maintain the issuance of this important Bulletin with some claims to solvency for such a long period. For this we also owe much in the way of appreciation to Lucile Myers, his secretary, the Iowa State Press, and the publishers. Despite its shortcomings, it served its intended purpose and was a worthy predecessor to the new International Journal of Systematic Bacteriology.

As Editor, Dr. Buchanan maintained a rigid code of procedure, insisting that all reports and other submissions from the various subcommit- tees on taxonomy be first approved by the Chairman of the ICSB and that nomenclatural matters had the approval where necessary of the Chairman of the Judicial Commission.

Apart from this, however, he took full responsibility for the acceptance of other material.

\section{Buchanan-a Personal Glimpse}

I first met Dr. Buchanan during a visit to Iowa in 1954 after a month-long sojourn with Dr. Breed. He made me most welcome and assisted me in every way with access to some of the rare taxonomic literature which he had accumulated at Ames. In subsequent years, I was to receive a series of critical and informative letters from him in relation to keys constructed at the request of Dr. Breed for the seventh edition of Bergey's Manual.

After my appointment to the chair of the ICSB, I received a continuous stream of unsolicited copies of replies which he had drafted to others who had written to him for advice on taxonomic matters. This action highlighted a characteristic of his which I have much admired. Rather than attack individuals for breaches of nomenclature by "notes to editors," he usually chose to pen his comments personally, leaving it to the recipient to do as he chose with the comments. To my knowledge, he has saved some quite eminent people from public, but not necessarily personal, embarrassment.

He adjusted surprisingly well to the rapid changes which have been imposed upon taxonomy by changing methods. He surprised many by his ready acceptance of numerical taxonomy as a new approach to classification, by the ready acceptance of modifications of the code to include the viruses, and by his later attitude to the separation of the viruses from the bacteria for nomenclatural purposes.

$\mathrm{He}$ was naturally apprehensive when the ICSB chose to dismember his code of nomenclature to provide for the new statutes of the ICSB and the new code of nomenclature for the bacteria. He caused me to sit patiently through a 2-day session while we went word-by-word through the proposed statutes in his office in 1969 to satisfy him of the utility of our intentions. He was informed of the activities of the drafting committee which was appointed in 1970 to draft the new code, but unfortunately he was unable to favor it with his comments.

Perhaps the most difficult period for him was 
his severance from the office of Chairman of the Judicial Commission, which he had held since its inception in 1939 to the time of the Moscow Congress in 1966. It was apparent to all concerned that with failing health he could not continue to cope with his numerous commitments and that the duties of the chairmanship of the Commission should pass to another person. He had reached the end of his current term of office as a Commissioner, and all had agreed that the term should not be extended and that he should be honored with life membership in the ICSB. I was asked if I would speak with him beforehand to "soften the blow."

I declined-seeking safety in the power of the pen in the aftermath! I wrote to him shortly after the Congress, explaining to him that the Commission and the Committee at large considered that he had done a tremendous job for systematic microbiology and that the members felt that "the task should be taken over by younger men."

His reply was not long in coming. It opened with the memorable and somewhat deflating remark "Thank you for your grandfatherly letter. What we need is not younger men but more competent ones!" He was then 83 , and Sneath and I were in our forties!

He survived this period by another 7 productive years. I am informed that on his last trip to the hospital he demanded to know "who authorized his transfer?" It is the spirit of men like Buchanan that has advanced science to what it is today, and such spirit does not die. Dr. Buchanan remains very much alive!

To his widow and associates of some 65 years, we say simply-thank you.

V. B. D. Skerman Chairman, ICSB 